\title{
KUALITAS PELAYANAN KESEHATAN INSTALASI GAWAT DARURAT RUMAH SAKIT UMUM DAERAH KOTA MAKASSAR
}

\section{HEALTH SERVICE QUALITY IN ACCIDENT AND EMERGENCY DEPARTMENT REGIONAL PUBLIC HOSPITAL MAKASSAR CITY}

\author{
Yunita Gobel ${ }^{1}$, Wahidin ${ }^{2}$, dan Muttaqin ${ }^{3}$ \\ ${ }^{1}$ Dinas Kesehatan Kota Makassar \\ email: yunita.gobel@yahoo.com \\ ${ }^{2}$ Sekolah Tinggi Ilmu Administrasi Negara - Lembaga Administrasi Negara, Makassar \\ e-mail: wahidin_mussi@yahoo.co.id \\ ${ }^{3}$ Sekolah Tinggi Ilmu Administrasi Negara - Lembaga Administrasi Negara, Makassar \\ e-mail: muttaqin_lan@yahoo.com
}

\begin{abstract}
Abstrak
Permasalahan utama dalam penelitian ini adalah "Bagaimanakah kualitas pelayanan Instalasi Gawat Darurat (IGD) Rumah Sakit Umum Darerah Kota Makassar ditinjau dari dimensi 1) Ketepatan waktu pelayanan; 2) Akurasi pelayanan; 3) Kesopanan dan keramahan dalam memberikan pelayanan; 4) Tanggung jawab; 5) Kelengkapan; 6) Kemudahan dalam mendapatkan pelayanan. Penelitian ini bertujuan untuk mengetahui kualitas pelayanan IGD RSUD Kota Makassar. Metode yang digunakan adalah metode deskritif kualitatif. Sumber data adalah informan yaitu kepala ruangan, direktur/wakil direktur pelayanan medik, pasien IGD, petugas (perawat/bidan dan dokter penanggung jawab pelaksana). Teknik pengumpulan data adalah wawancara, observasi dan telaah dokumen. Data dalam penelitian ini ditampilkan secara triagulasi dan dibahas secara interpretatif berdasarkan teori dan fakta. Hasil penelitian menunjukkan pada indikator ketepatan waktu pelayanan sudah baik. Dilihat dari proses jadwal kehadiran petugas secara bergiliran selama 24 jam sudah tepat waktu sesuai dengan jadwal yang telah ditentukan. Indikator akurasi pelayanan termasuk dalam kategori berkualitas dimana kemampuan petugas selalu mengupayakan agar perawatan pasien minimal dari kesalahan. Indikator kesopanan dan keramahan termasuk dalam kategori cukup baik, dilihat dari cara melayani pasien dengan prinsip 5S (Senyum, Sapa, Salam, Sopan, Santun). Namun teknik berkomunikasi masih perlu diperbaiki. Indikator tanggung jawab sudah dalam kategori baik karena sudah ada jaminan keamanan dan keselamatan pasien. Indikator kelengkapan dalam kategori baik dengan kondisi rumah sakit yang bersih dan sarana yang ada sudah lengkap, hanya perlu adanya kepedulian dari pegawai untuk menjaga sarana prasarana yang ada. Indikator kemudahan untuk mendapatkan pelayanan pasien dimudahkan oleh fasilitas pendukung di rumah sakit juga prosedur pelayanan yang mudah, jelas dan tidak berbelit-belit.
\end{abstract}

Kata Kunci: Kualitas Pelayanan Kesehatan, Instalasi Gawat Darurat, Rumah Sakit Umum Daerah Kota Makassar 
Yunita Gobel, Wahidin, Muttaqin/Jurnal Administrasi Negara, Volume 24 Nomor 3 (2018)/ 177-188

\begin{abstract}
This study's focus on service quality of Accident and Emergency $(A \& E)$ department at regional public hospital in Makassar City and analyzied service quality dimensions such as time service, 1) Service accuracy, 3) Courtesy and guidance in providing services; 4) Responsibility; 5) Completeness; 6) Ease in getting services. This study is using qualitative descriptive method. Sources of the data were informants as Head of Space, Director/Deputy of Medical Services, Patient of ER (Emergency Room), nurses/midwives and Doctor in Charge of Patients. The data collection techniques were from interviews, observation and document review. The data validity was check using triangulation technique. The results showed in service timeliness dimension was already appropriate according to the 24 hours shift schedule of all of the staff. The accuracy service indicator was in a certain quality category. The staff were always strive to afford mistakes while handling the patients. The politeness and sociability indicators was good enough, according to how they treat the patuents with $5 S$ principle. Eventhough the communication technique still needs to be fixed. The responsibility indicator assesment was in a good category due to assurance of patient safety. The completeness indicators was in a good category due to the clean hospital area and the facilities were already complete but employees needs to maintain the facilities. In the ease in getting services indicator which has a certain quality due to the complete supporting facilities that made service easier and convenient serve services also not convoluted.
\end{abstract}

Keywords: Health Service Quality, Accident and Emergency Department, Makassar Regional Public Hospital

\section{PENDAHULUAN}

Kualitas pelayanan adalah tingkat unggulan yang diharapkan dan pengendalian atas tingkat keunggulan tersebut untuk memenuhi tingkat kebutuhan pelanggan. Kualitas pelayanan merupakan kepuasan pelanggan sepenuhnya. Suatu produk berkualitas apabila dapat memberi kepuasan sepenuhnya kepada konsumen, yaitu sesuai dengan apa yang diharapkan konsumen atas suatu produk atau jasa.

Rumah sakit merupakan pelayanan kebutuhan dasar dibidang kesehatan, karena kesehatan merupakan hal yang terpenting bagi warga masyarakat untuk tercapainya kesejahteraan. Disamping itu juga rumah sakit termasuk klasifikasi pelayanan publik pada pelayanan umum dibidang jasa. Karena rumah sakit juga menyediakan pelayanan yang menghasilkan berbagai bentuk jasa yang dibutuhkan oleh publik.

Instalansi Gawat Darurat (IGD) merupakan unit Rumah Sakit yang memberikan perawatan pertama kepada pasien. Unit ini dipimpin oleh seorang dokter jaga dengan tenaga dokter ahli dan berpengalaman dalam menangani PGD (Pelayanan Gawat Darurat), yang kemudian bila dibutuhkan akan merujuk pasien kepada dokter spesialis tertentu. Kementrian Kesehatan telah mengeluarkan kebijakan mengenai Standar Instalansi Gawat Darurat 
(IGD) Rumah Sakit yang tertuang dalam Keputusan Menteri Kesehatan Republik Indonesia Nomor 856 tahun 2009 untuk mengatur standarisasi pelayanan gawat darurat di rumah sakit.

Berdasarkan data pelayanan kesehatan IGD di RSUD Kota Makassar pada tahun 2014-2016 menunjukkan bahwa terjadi penurunan jumlah pasien pada tahun 2014 sebanyak 8867 pasien, 2015 sebanyak 8367 pasien, dan tahun 2016 sebanyak 6072 pasien. Guna mengetahui kualitas IGD di RSUD Kota Makassar maka peneliti dalam hal ini menggunakan indeks kepuasan masyarakat menurut Vincent Gaspersz. Dimana kualitas pelayanan IGD di RSUD Kota Makassar dapat dievaluasi dengan mengkaji 6 unsur yang relevan terhadap pelayanan di IGD sebagai berikut: ketepatan dalam pelayanan, akurasi pelayanan, kesopanan dan keramah-tamahan dalam memberikan layanan, tanggung jawab, kelengkapan, dan kemudahan mendapatkan layanan.

\section{METODE PENELITIAN}

Penelitian ini menggunakan metode deskripitif dengan pendekatan kualitatif dengan tujuan untuk melihat atau mengamati kanyataan mendalam dilapangan tentang konsep atau indikator-indikator yang akan diteliti dengan menggunakan instrument penelitian. Penelitian ini berlokasi di Rumah Sakit Umum Daerah Kota Makassar khususnya pada Instalasi Gawat Darurat, data informasi yang di dapatkan melalui wawancara yang akan digali dari pasien di IGD RSUD Kota Makassar sebanyak 17 orang. Teknik dan instrument pengumpulan data dilakukan dengan melakukan wawancara yang didukung dengan observasi dan dokumentasi.

Dalam penelitian ini, prosedur pengolahan data yang dilakukan yaitu secara sistematis dengan tahapan Klasifikasi materi data, Mengolah data, Mendeskripsikan, dan Uji validitas dan reabilitas. Metode analisis data yang digunakan adalah deskriptif kualitatif. Metode ini digunakan untuk menyajikan data secara naratif, dengan menggambarkan data yang terkumpul sebagaimana adanya, dan memberikan argumentasi dengan jelas dari analisis data yang terkumpul sesuai dengan pertanyaan penelitian, kemudian mengaitkan dengan teori yang diangkat sehingga mampu menjelaskan secara keseluruhan mengenai apa yang menjadi fokus dalam penelitian ini.

\section{HASIL PENELITIAN}

Distribusi jawaban informan terhadap kualitas pelayanan Instalasi Gawat Darurat 
pada Rumah Sakit Umum Daerah Kota Makassar dapat diketahui melalui mutu pelayanan pasien. Adapun tanggapan responden yang ditinjau dari tiap-tiap mutu pelayanan jasa menurut pendekatan dimensi kualitas pelayanan oleh Vincent Gaspersz (Bustami, 2011:6-7) dapat dilihat dari (Ketepatan waktu pelayanan, Akurasi pelayanan, Kesopanan dan keramahan dalam memberikan pelayanan, Adanya tanggungjawab, kelengkapan dan kemudahan dalam mendapatkan pelayanan).

\section{Ketepatan Waktu}

Ketepatan waktu pelayanan yang dimaksud adalah kecepatan kontak pertama pelayanan, waktu tunggu rawat inap atau waktu tunggu rujukan. Proses waktu untuk menunggu pelayanan pertama pada pasien gawat, darurat atau gawat darurat yang datang ke IGD adalah response time. Berdasarkan hasil observasi di ruang IGD RSUD Kota Makassar mengenai response time waktu untuk menunggu pelayanan pertama pada pasien gawat, darurat atau gawat darurat yang datang ke IGD, response time yang diberikan petugas medis (dokter/perawat, bidan) sesuai dengan standar waktu dari setiap jenis pelayanan yang berbeda di IGD RSUD Kota Makassar.
Menurut wawancara dengan Kepala Seksi Monitoring dan Evaluasi Pelayanan Medik pada tanggal 11 November 2017 diperoleh bahwa "dokter yang ditugaskan untuk menjaga di UGD ini ada 6 orang, setiap dokter mempunyai tanggung jawab pada waktu jaga yang sesuai dengan jadwal yang sudah ditentukan, jika dokter penanggung jawab terlambat atau berhalangan, dokter pengganti yang sudah diberi wewenang siap sedia menggantikan tanggung jawab dokter jaga waktu itu".

\section{Akurasi Pelayanan}

Akurasi pelayanan adalah cara melayani, membantu, menyiapkan, menyelesaikan keperluan, kebutuhan seseorang atau sekelompok orang. Dari defenisi ini, obyek yang dilayani adalah individu, pribadi-pribadi (seseorang), dan organisasi (sekelompok anggota organisasi). Keterampilan dan keahlian tersebut, pihak yang melayani mempunyai posisi atau nilai lebih dalam kecakapan tertentu, sehingga mampu memberikan bantuan dalam menyelesaikan suatu keperluan, kebutuhan individu atau organisasi (Denhardt \& Denhardt, 2003:7).

Berdasarkan hasil wawancara dengan informan selaku Kepala Ruang Instalasi Gawat Darurat pada tanggal 11 November 
2017 terkait akurasi pelayanan menjelaskan bahwa: "setiap saat saat saya selaku kepala ruangan IGD untuk mengingatkan kepada seluruh petugas yang bertugas di area IGD ini untuk tetap bekerja sesuai standar operasional prosedur yang ada demi menghindari ketimpangan yang mengakibatkan kesalahan dalam pelayanan pasien”.

Dari hasil wawancara diatas, menunjukkan bahwa dalam penangganan pasien harus sesuai dengan prosedur, ini dilakukan agar pasien terhindar dari kesalahan dalam bertindak. Hal ini tentu berpengaruh pada tingkat kualitas pelayanan yang diteriama oleh pasien dimana proses penanganan pasien yang mengutamakan pelayanan berkualitas yang diberikan benar dan sesuai dengan indikasi penyakit pasien yang sesuai dengan SOP Instalasi Gawat Darurat RSUD Kota Makassar dimana petugas cepat tanggap pada pasien yang membutuhkan pelayanan.

\section{Kesopanan dan Keramahan dalam memberikan pelayanan}

Kesopanan dan keramahan petugas yaitu sikap dan perilaku petugas dalam memberikan pelayanan kepada masyarakat/pasien secara sopan dan ramah serta saling menghargai dan menghormati.
Berdasarkan Keputusan MENPAN No.63 tahun 2003 ada beberapa prinsip pelayanan berdasarkan indeks kepuasan masyarakat adalah sebagai berikut: Kesederhanaan (prosedur pelayanan), kejelasan petugas pelayanan, kesopanan dan keramahan petugas, tanggung jawab petugas, kedisplinan dll. Kompleksitas penerapan fungsi aktuasi di sebuah RS dipengaruhi oleh dua faktor (Muninjaya, 2011:155) salah satunya Pelaksanaan fungsi aktuasi staf pelaksana pelayanan di RS, tidak saja terkait dengan jumlah, keragaman profesi, dan komitmen, tetapi juga sikap, etika dan kompetensinya.

Berdasarkan hasil wawancara dengan kepala ruangan IGD pada tanggal 14 November 2017, Tentang keramahan dan kesopanan petugas dalam melayani pasien menjelaskan bahwa

"dari pantauan saya kepada mereka petugas di IGD yang selama ini saya perhatikan bahwa semua peawai yang menjadi pelayan di sini sudah memperlihatkan sikap kesopanannya, baik itu kepada pasien yang masuk maupun kepada sesama petugas itu sendiri."

Hasil wawancara diatas, menunjukkkan bahwa petugas sudah menunjukkan sikap dan perilaku yang baik dalam memberikan pelayanan kepada pasien dimana dalam 
melayani sudah sopan dan ramah serta saling menghargai dan menghormati. Hasil rekapitulasi tanggapan pasien atas kesopanan dan keramahan petugas dalam memberikan pelayanan kepada pasien di Instalasi Gawat Darurat RSUD Kota Makassar oleh petugas dalam memberikan pelayanan masih tergolong baik. Kemudian pada proses pelayanan pada pasien dalam berkomunikasi masih perlu dibimbing untuk selalu berkomunikasi dengan baik untuk pasien atau sesama petugas agar pelayanan berjalan dengan baik. Membangun komunikasi yang baik antar pasien dengan pegawai atau sesama pegawai merupakan hal yang mutlak untuk dilakukan. Keadaan yang bertolak belakang antar pasien dengan pegawai atau pegawai dengan pegawai bisa dipersatukan dengan komunikasi yang baik dan dengan bijak.

\section{Tanggung Jawab}

Tanggung Jawab yaitu kejelasan wewenang dan tanggunjawab dalam penyelenggaraan dan penyelesaian pelayanan dengan menindaklanjuti sesegera mungkin terhadap keluhan pasien.

Tanggapan Kepala Ruangan Instalasi Gawat Darurat pada tanggal 11 November 2017 saat dilakukan wawancara mengenai keselamatan pasien dalam memberikan tindakan bagi petugas memberi tanggapan bahwa:

"Siapapun petugas baik dokter, perawat/bidan yang melayani pasien setiap waktu sudah mempunyai wewenang dan tanggung jawab masing-masing. Untuk menjamin keselamatan pasien petugas khususnya di ruang Instalasi gawat darurat ini selalu bekerja sesuai dengan Standar Operasional Prosedur yang ada”.

Berdasarkan dari hasil wawancara diatas, dapat dikatakan bahwa petugas (Dokter, Perawat/Bidan) sudah mempunyai wewenang dan tanggung jawab masingmasing. Dalam melakukan pelayanan pasien khususnya dalam melakukan tindakan petugas sudah bekerja sesuai dengan SOP yang ada sesuai kemampuannya.

Dari hasil semua wawancara dengan informan diatas sejalan dengan observasi peneliti atas proses penanganan pasien dengan selalu memperhatikan pemasangan label identitas pasien untuk memberikan perlindungan keselamatan dari tindakan yang akan dilakukan.

\section{Kelengkapan}

Kelengkapan yaitu menyangkut sarana dan prasarana yang ada, lengkap dan memadai yang dapat menunjang terhadap pelayanan di rumah sakit. Menurut wawancara pada tanggal 11 November 2017 dengan kepala ruang Instalasi Gawat Darurat 
memberi tanggapan bahwa "Kalau mengenai sarana prasarana yang ada di ruangan kami saya rasa cukup baik, alat - alat yang dapat menunjang dalam pemeriksaan khususnya yang berhubungan dengan pemeriksaan awal pasien sudah lengkap. Sarana untuk menunjang kebersihan Rumah sakit juga ada, untuk masalah AC dan Kamar mandi yang sering bermasalah, segera kami laporkan dan tim sarana segera menindaklanjuti untuk perbaikan, untuk perawatan alat yang ada dan sudah rusak dalam proses perbaikan".

Dari hasil penjelasan diatas, sarana yang ada di Instalasi Gawat Darurat RSUD Kota Makassar yang dapat menunjang dalam pemeriksaan di Instalasi Gawat Darurat RSUD Kota Makassar sudah lengkap.Tim sarana segera bertindak jika ada yang rusak di Instalasi Gawat Darurat RSUD Kota Makassar.

Berdasarkan wawancara pada tanggal 15 November 2017 dengan pasien memberi tanggapan bahwa:

"kalau masalah kelengkapan sarana disini saya rasa cukup mi sesuai standar Rumah Sakit Umum lainnya karena tidak semua pasien di rujuk karena alat-alat disini sudah mulai di lengkapi tapi tetap perlu ditingkitkan, seperti di kamar mandi kadang air tidak mengalir".

Dari hasil wawancara dengan pasien rawat inap ini bahwa walaupun alat-alat sudah lengkap dalam menunjang pemeriksaan tapi perlu jadi perhatian dari manajemen Instalasi Gawat Darurat RSUD Kota Makassar adalah mengenai ketersediaan air yang cukup di rumah sakit. Hal ini untuk menunjang dalam pemberian pelayanan, namun saat di komfirmasi dengan tim sarana mengatakan bahwa jika air tidak mengalir berarti petugas sementara membersihkan bak penampungan.

\section{Kemudahan Mendapatkan Pelayanan}

Kemudahan mendapatkan layanan adalah akses yang tidak berbelit-belit dengan alur pelayanan yang jelas, tidak membedabedakan pelayanan berdasarkan status pasien. Berdasarkan hasil observasi di IGD RSUD Kota Makassar sarana fisik berupa tersedianya ambulance, kursi roda, dan tempat tidur telah tersedia sebagai alat transportasi pasien untuk memudahkan pelayanan. Selain itu, sarana fisik berupa pemeriksaan penunjang maupun akses perawatan lanjut tersedia dan berada dekat dari IGD untuk memudahkan mobilisasi pasien. Adapun sumber daya manusia meliputi petugas medis dan non medis, selalu standby di ruangan untuk memudahkan pasien dalam mendapatkan pelayanan.

Berikut hasil wawancara pada tanggal 11 November 2017 dengan Kepala Instalasi 
Gawat Darurat RSUD Kota Makassar lantai empat tentang alur pelayanan pasien menjelaskan bahwa

"Menurut saya mengenai kemudahan dalam mendapatkan pelayanan semuanya sudah sesuai alur tidak ada perbedaan antara pasien umum dan BPJS".

Dari hasil wawancara diatas, dapat menjelaskan bahwa demi kemudahan pasien yang masuk ke Instalasi gawat Darurat RSUD Kota Makassar tidak dibedakan dengan fasilitas apa yang menjamin pasien, semua menerima pelayanan yang sama

\section{PEMBAHASAN}

Karakteristik pelayanan yang diinginkan pelanggan menurut Gaspersz yang harus diperhatikan dalam perbaikan kualitas jasa, guna mencapai tingkat kepuasan yang optimal perlu diperhatikan beberapa faktor atau atribut layanan. Pelayanan kesehatan yang baik menurut Azwar (2014:38-39) harus memenuhi syarat pokok salah satunya Berkualitas, yaitu yang menunjuk pada tingkat kesempurnaan pelayanan kesehatan yang diselenggarakan, yang di satu pihak dapat memuaskan para pemakai jasa pelayanan, dan tata lain penyelenggaraanya sesuai dengan kode etik dan standar yang telah ditetapkan
Ketepatan dalam pelayanan disini perlu diperhatikan dan digaris bawahi sehubungan degan lamanya waktu tunggu dan waktu proses, juga ketentuan jam pelayanan jam pembukaan dan penutupan loket layanan. Dalam penanganan pasien gawat darurat di instalasi gawat darurat ada filosofinya yaitu Time Saving is Life Saving artinya bahwa semua tindakan yang dilakukan pada saat kondisi gawat darurat haruslah benar-benar efektif serta efisien. Hal ini dikarenakan bahwa pasien dapat kehilangan nyawa hanya dalam hitungan menit saja. Berhenti nafas selama 2-3 menit pada manusia dapat menyebabkan kematian yang fatal. Berdasarkan hasil observasi dan wawancara mendalam didapatkan bawah ketepatan waktu pelayanan yang dilakukan oleh Perawat/DPJP terjadwal dengan baik dan ruang dalam ruang IGD selalu sedia dokter jaga yang siap melayani pasien gawat darurat selama 24 jam pelayanan. Begitu pula dengan proses pelayanan di IGD waktu penanganan para petugas kesehatan (response time) sesuai dengan standar waktu pelayanan IGD. Dalam dimensi ketepatan waktu pelayanan termasuk dalam kategori baik.

Akurasi pelayanan yang dimaksud adalah perlu dipastikan reliabilitas pelayanan dan harus diusahakan bebas dari kesalahan- 
kelasalahan. Berdasarkan maklumat pelayanan RSUD Kota Makassar bahwa pimpinan dan seluruh staf menjamin penyediaan pelayanan kesehatan sesuai dengan standar pelayanan RSUD yang telah ditetapkan. Pada dimensi ini termasuk dalam kategori berkualitas dimana kemampuan petugas selalu mengupayakan agar perawatan pasien minimal dari kesalahan. Berdasarkan hasil wawancara dan observasi tindakan dokter/perawat pada pasien sudah sesuai dengan Standar Operasional Prosedur (SOP) yang ditetapkan oleh ruah sakit.

Kesopanan dan keramahan petugas yaitu sikap dan perilaku petugas dalam memberikan pelayanan kepada masyarakat/pasien secara sopan dan ramah serta saling menghargai dan menghormati. Dari hasil wawancara dengan informan dan hasil observasi peneliti atas proses penangganan pasien dengan membudayakan sikap ramah, lincah dan gesit melalui $5 \mathrm{~S}$ (Senyum, Sapa, Salam, Sopan dan Santun), oleh petugas seperti petugas sudah melaksanakan tindakan dengan cepat dan tepat, dan memberikan perhatian penuh jika pasien kesakitan. Namun masih ada petugas (Dokter, Perawat/Bidan) yang berkomunikasi dengan suara tinggi atau kasar, kurang senyum, marah/menegur bawahan didepan pasien. Hal ini diakibatkan oleh jadwal shif yang terlalu padat sehingga pegawai merasa kelelahan dalam bekerja.

Tanggung jawab yaitu kejelasan wewenang dan tanggunjawab dalam penyelenggaraan dan penyelesaian pelayanan dengan menindaklanjuti sesegera mungkin terhadap keluhan pasien. Berdasarkan hasil observasi kelengkapan keselamatan pasien IGD RSUD Kota Makassar kelengkapan SIP/SIK petugas IGD sudah lengkap karena menjadi bukti bahwa petugas telah dinyatakan mampu secara keilmuan dan memiliki tanggung jawab untuk melakukan tindakan terhadap pasien sesuai dengan pengetahuan dan kompetensi mereka. Selain itu, ketersediaan penanggulangan bencana juga lengkap di IGD hal ini penting karena merupakan tanggung jawab rumah sakit untuk melindungi pasien dari risiko bahaya yang kecil-kecilnya. Sehingga pada indikator tanggung jawab sudah dalam kategori baik karena sudah ada jaminan keamanan dan keselamatan pasien.

Adapun kelengkapan menyangkut ketersediaan ruang pelayanan, sarana pendukung serta komplementer layanan lainnya. Pada hasil observasi kelengkapan fasilitas ruangan IGD RSUD Kota Makassar meliputi sarana medik sudah lengkap dan dapat menjamin efisiensi pelayanan pasien gawat darurat dalam waktu 24 jam terus- 
menerus. Jumlah tempat tidur di IGD juga termasuk dalam batasan cukup untuk menampung volume pasien setiap hari. Sehingga pada indikator kelengkapan dalam kategori baik dengan kondisi rumah sakit yang bersih dan sarana yang ada sudah lengkap, hanya perlu adanya kepedulian dari pegawai untuk menjaga sarana prasarana yang ada.

Kemudahan mendapatkan layanan adalah akses yang tidak berbelit-belit dengan alur pelayanan yang jelas, tidak membedabedakan pelayanan berdasarkan status pasien. Berdasarkan hasil observasi di IGD RSUD Kota Makassar sarana fisik berupa tersedianya ambulance, kursi roda, dan tempat tidur telah tersedia sebagai alat transportasi pasien untuk memudahkan pelayanan. Selain itu, sarana fisik berupa pemeriksaan penunjang maupun akses perawatan lanjut tersedia dan berada dekat dari IGD untuk memudahkan mobilisasi pasien. Indikator kemudahan mendapatkan pelayanan dalam kategori berkualitas yaitu untuk mendapatkan pelayanan pasien dimudahkan oleh fasilitas yang disediakan di rumah sakit selain itu prosedur pelayanan yang mudah, jelas dan tidak berbelit-belit.

\section{KESIMPULAN DAN SARAN}

Berdasarkan hasil penelitian tentang analisis kualitas pelayanan yang dilakukan di Instalasi Gawat Darurat Rumah Sakit Umum Daerah Kota Makassar, maka penulis dapat menarik kesimpulan bahwa: Pada indikator ketepatan waktu pelayanan berada dalam kategori baik. Ini dapat dilihat dari proses jadwal pelayanan rumah sakit (visite) yang dilakukan oleh Dokter Penanggung Jawab Pelayanan (DPJP) sudah tepat waktu sesuai dengan Standar Operasional Prosedur (SOP) atau aturan yang ada. Pada indikator akurasi pelayanan petugas kesehatan dengan memberikan keterangan yang cepat dan tepat atas keadaan pasien. Pasien mengharapkan pelayanan yang diberikan IGD RSUD Kota Makassar adalah pelayanan yang siap tanggap dan nyaman terhadap keluhan penyakit pasien. Pada perawat dan dokter mampu memberikan pertolongan pertama, menetapkan diagnosis penyakit dan bebas dari kesalahan-kesalah. Pelayanan yang diberikan sesuai dengan indikasi penyakit pasien dengan mengikoti Standar Prosedur operasional RSUD Kota Makassar. Pada indikator kesopanan petugas kesehatan berkomunikasi dengan selalu menanyakan respon balik terhadap tindakan yang diberikan. Pelayanan di IGD RSUD Kota 
Makassar menunjukkan bahwa petugas sudah menunjukkan sikap dan perilaku yang baik dalam memberikan pelayanan kepada pasien dimana dalam melayani pasien sudah sopan dan ramah serta saling menghargai dan menghormati. Pada indikator tanggung jawab termasuk dalam kategori baik. Hal ini dapat dilihat dari adanya keamanan dan keselamatan pasien, perlindungan dari resiko yang sekecil-kecilnya yang dapat terjadi kepada pasien. Ini dapat dilihat dari proses pelayanan dimana saat pasien masuk ke ruang Instalasi Gawat Darurat petugas segera memeriksa identitas dan mencocokkan dengan Rekam Medik (RM) nantinya pasien agar terhindar dari resiko kesalahan bertindak yang dapat mengancam keselamatan pasien. Pada indikator kelengkapan yaitu sarana prasarana termasuk dalam kategori baik. Hal ini dapat dilihat dari kondisi rumah sakit yang bersih. Alat-alat yang mendukung dalam pelayanan sudah lengkap, hanya saja kelihatan kurang dipelihara sehingga banyak yang rusak. Begitupun juga dengan kamar mandi masih ada yang sering bermasalah namun cepat ditindaklanjuti oleh penanggung jawab sarana rumah sakit. Pada indikator kemudahan mendapatkan pelayanan termasuk dalam kategotri berkualitas. Hal ini dilihat dari prosedur pelayanan yang mudah, lancar, cepat dan tepat serta tidak berbelit- belit, juga pasien sudah menempati ruang rawat inap sesuai dengan pertanggungannya tampah membeda-bedakan pasien UMUM atau pasien BPJS.

Untuk tetap mempertahankan dan meningkatkan kualitas pelayanan yang sudah ada di Instalasi Gawat Darurat Rumah Sakit Umum Daerah Kota Makassar, maka peneliti memberikan rekomendasi adalah Untuk meningkatkan disiplin pegawai dalam melaksanakan pelayanan khususnya ketepatan waktu pelayanan visite dokter maka kebijakan atau SOP yang sudah dibuat harus diterapkan dan diharapkan kepada Kepala Ruangan selaku Pimpinan di Instalasi Gawat Darurat Rumah Sakit Umum Daerah Kota Makassar memberikan teguran/sanksi jika SOP tersebut tidak dilaksanakan. Untuk menghindari kesalahan-kesalahan dalam menentukan suatu diagnosa atau melakukan suatu tindakan dalam pelayanan maka diharapkan kepada Kepala Ruangan sebagai Pimpinan Instalasi Gawat Darurat Rumah Sakit Umum Daerah Kota Makassar untuk memberikan dorongan serta izin kepada pegawai yang ingin melanjutkan pendidikan atau menganjurkan pegawai untuk selalu mengikuti seminar-seminar kesehatan yang terkini (update) dan selalu mengingatkan pegawai untuk selalu bekerja dengan berpedoman kepada Standar Operasional 
Prosedur (SOP) yang ada di Instalasi Gawat Darurat Rumah Sakit Umum Daerah Kota Makassar.

Melihat masih adanya pegawai yang dalam berkomunikasi baik itu cara berkomunikasi pegawai dengan pasien atau cara berkomunikasi petugas dengan petugas masih kurang sehingga diharapkan kedepannya Kepala Ruangan selaku Pimpinan di Instalasi Gawat Darurat Rumah Sakit Umum Daerah Kota Makassar untuk memberikan atau mengadakan pelatihan tentang cara berkomunikasi dengan baik dalam memberikan pelayanan prima. Untuk meningkatkan tanggung jawab pegawai terhadap pekerjaan yang dilakukan, diharapakan sebelum melakukan suatu tindakan semua pegawai selalu berpedoman pada SOP yang sudah dibuat agar terhindar dari kesalahan-kesalahan dalam melakukan tindakan.

Untuk lebih meningkatakan pelayanan kepada pasien penyediaan sarana yang ada di rumah sakit harus terjaga dengan baik. Oleh karena itu petugas diharapkan selalu menjaganya agar alat-alat tersebut lebih awet sehingga tidak menggangu proses pelayanan. Dalam memenuhi kemudahan mendapatkan pelayanan diharapkan kedepannya Kepala Ruangan Instalasi Gawat Darurat Rumah Sakit Umum Daerah Kota Makassar selalu mengingatkan pegawai agar jangan mempersulit pasien dalam memperoleh layanan. Untuk mengetahui keinginan pasien dan tindak lanjut yang cepat dengan tersedianya kotak saran bagi pasien, agar petugas segera menindaklanjuti setiap saat sehingga kedepannya bisa lebih meminimalisir keluhan pelanggan terhadap peningkatan kualitas layanan di rumah sakit.

\section{REFERENSI}

Azwar, A. 2014. Tantangan Pendanaan Unit Gawat Darurat. Majalah Kedokteran Indonesia, 43, (3), p 152-153.

Bustami. 2011. Penjaminan Mutu Pelayanan Kesehatan \& Akseptabilitasnya. Jakarta: Erlangga.

Denhardt, Janer V, Robert B. Denhardt. 2003. The New Public Service: Serving Not Steering. Armonk, N.Y: M.E.Sharpe.

Muninjaya, Gde AA. 2011. Manajemen Mutu Pelayanan Kesehatan. Jakarta: EGC.

Keputusan Menteri Kesehatan Republik Indonesia Nomor 856 Tahun 2009, tentang Standar Instalasi Gawat Darurat (IGD) Rumah Sakit. 